A responsabilidade penal do infrator de medida sanitária preventiva: uma abordagem a partir da teoria de Günther Jakobs

La responsabilidad penal del infractor de medida de salud preventiva: aproximación a la teoría de Günther Jakobs

Autores: Cláudio Macedo de Souza, Bruno Carminati Cimolin, Rafael Pereira

DOI: https://doi.org/10.25058/1794600X.1888 


\title{
A responsabilidade penal do infrator de medida sanitária preventiva: uma abordagem a partir da teoria de Günther Jakobs*
}

\author{
La responsabilidad penal del infractor de medida de salud \\ preventiva: aproximación a la teoría de Günther Jakobs
}

\author{
The criminal responsibility of the preventive health measure \\ infractor: an approach to the Günther Jakobs theory
}

\author{
Cláudio Macedo de Souza ${ }^{a}$ \\ clauruas@gmail.com \\ Bruno Carminati Cimolin ${ }^{b}$ \\ bcimolin@yahoo.com.br
}

Rafael Pereirac rafaelpereir_a@hotmail.com

Fecha de recepción: 15 de febrero de 2021 Fecha de revisión: 30 de marzo de 2021 Fecha de aceptación: 30 de abril de 2021

\section{DOI: https://doi.org/10.25058/1794600X.1888}

\section{Para citar este artículo:}

Miranda, H. S.; Gonçalves, J. R. y Siqueira, M. V. B. (2021). A responsabilidade penal do infrator de medida sanitária preventiva: uma abordagem a partir da teoria de Günther Jakobs. Revista Misión Jurídica, 14(21), 29-42.

\section{RESUMO}

Este artigo objetiva compreender a legitimidade da aplicação da sanção penal prevista no artigo 268 do Código Penal para responsabilizar infratores de medidas sanitárias preventivas na contenção da doença de Covid-19, na perspectiva da Teoria de Günther Jakobs. Vive-se uma crise de saúde pública no Brasil e no mundo. Neste cenário, o poder público anunciou medidas a fim de impedir a propagação do vírus. Nesta direção, a técnica de tipificação compatível com a antecipação máxima da proteção da saúde é o perigo abstrato. Portanto, diante da possibilidade concreta do Direito Penal deixar de cumprir sua função de proteção fragmentária e subsidiária, indagou-se: "Em qual modelo teórico, a responsabilidade penal imposta ao infrator da normatividade para conter

\footnotetext{
*Artigo de reflexão.

a. Professor Doutor dos Cursos de Graduação e do PPGD - Programa de Pós-Graduação em Direito da UFSC - Universidade Federal de Santa Catarina; Doutor em Ciências Penais pela UFMG - Universidade Federal de Minas Gerais e Coordenador do GDPI - Grupo de Pesquisa de Direito Penal Internacional CNPq - UFSC http://dgp.cnpq.br/dgp/espelhogrupo/214070 Lattes: http://lattes.cnpq.br/793530261509569 Orcid: https://orcid.org/0000-0002-4603-3460

b. Mestrando em Direito pelo Programa de Pós-Graduação em Direito da Universidade Federal de Santa Catarina (UFSC); Especialista em Direito Penal e Direito Processual Penal pela UNISINOS - Universidade do Vale do Rio dos Sinos e Especialista em Perícia Criminal e Ciências Forenses pelo IPOG - Instituto de Pós-Graduação e Graduação. Lattes: http://lattes.cnpq.br/3817960612297850 Orcid: https://orcid. org/0000-0002-5321-9052

c. Mestrando em Direito pelo Programa de Pós-Graduação em Direito da Universidade Federal de Santa Catarina (UFSC). Bacharel em Direito pela Universidade Estadual de Maringá (UEM). Lattes: http://lattes.cnpq.br/8636666989537354 Orcid: https://orcid.org/0000-0002-25734903
} 
a pandemia buscará legitimidade?" Supõe-se que, a sua legitimidade encontrará respaldo na Teoria Sistêmica, pois ao praticar a conduta proibida, o agente rompe expectativas normativas e a pena passa a ter como função demonstrar para a sociedade que, apesar da violação da norma, é possível confiar na sua vigência. Com foco na pesquisa bibliográfica, considerou-se o conceito de crime o qual deixa de proteger a saúde e passa a proteger a estabilidade normativa. Ademais, foi metodologicamente ponderado o conflito entre o direito à liberdade de locomoção e o direito à saúde da coletividade, diante da polêmica em torno da proibição de circulação de pessoas em locais públicos sem o uso obrigatório de máscara de proteção individual.

\section{PALAVRAS-CHAVE:}

Teoria sistêmica; Sanção penal; Pandemia de Covid-19; Artigo 268 do Código Penal; Saúde pública; Princípio da fragmentariedade.

\section{ABSTRACT}

This article aims to understand the legitimacy of the application of the criminal sanction provided for in article 268 of the Penal Code to hold offenders of preventive health measures in order to contain Covid-19 disease, from the perspective of Günther Jakobs Theory. There is a public health crisis in Brazil and in the world. In this scenario, the public authorities announced measures to prevent the spread of the virus. In this sense, the typification technique compatible with the maximum anticipation of health protection is the abstract danger. Therefore, in view of the concrete possibility of Criminal Law failing to fulfill its function of fragmentary and subsidiary protection, it was asked: "In what theoretical model, will the criminal responsibility imposed on the infringer of norms to contain the pandemic seek legitimacy?" It is assumed that, its legitimacy will find support in the Systemic Theory, because when practicing the prohibited conduct, the agent breaks normative expectations and the penalty starts to demonstrate to society that, despite the violation of the norm, it is possible to trust in its validity. With a focus on bibliographic research, the concept of crime was considered, which ceases to protect health and starts to protect normative stability. In addition, the conflict between the right to freedom of movement and the right to health of the community was methodologically considered, given the controversy surrounding the ban on the movement of people in public places without the mandatory use of an individual protection mask.

\section{KEY-WORDS:}

Systemic theory; Penal sanction; Covid-19 pandemic; Article 268 of the Penal Code; Public health; Fragmentation principle.

\section{RESUMEN}

Este escrito tiene como objetivo comprender la legitimidad de la aplicación de la sanción penal prevista en el artículo 268 del Código Penal para detener a los infractores de las medidas preventivas de salud con el fin de contener la enfermedad Covid-19, desde la perspectiva de la Teoría de Günther Jakobs. Hay una crisis de salud pública en Brasil y en el mundo. En tal escenario, las autoridades públicas anunciaron medidas para prevenir la propagación del virus. En este sentido, la técnica de tipificación compatible con la máxima anticipación de protección de la salud es el peligro abstracto. Por tanto, ante la posibilidad concreta de que el Derecho penal incumpla su función de protección fragmentaria y subsidiaria, se preguntó: ¿En qué modelo teórico buscará legitimidad la responsabilidad penal impuesta al infractor de normas para contener la pandemia? Se asume que su legitimidad encontrará sustento en la Teoría Sistémica, pues al practicar la conducta prohibida, el agente rompe las expectativas normativas y la sanción comienza a demostrar a la sociedad que, a pesar de la violación de la norma, es posible confiar en su validez. Con un enfoque en la investigación bibliográfica, se consideró el concepto de delito, que deja de proteger la salud y pasa a proteger la estabilidad normativa. Además, se consideró metodológicamente el conflicto entre el derecho a la libertad de circulación y el derecho a la salud de la comunidad, dada la controversia en torno a la prohibición de la circulación de personas en lugares públicos, sin el uso obligatorio de una máscara de protección individual.

\section{PALABRAS CLAVE}

Teoría sistémica; sanción penal; pandemia de COVID-19; artículo 268 del Código Penal; salud pública; principio de fragmentación. 


\section{INTRODUÇÃO}

0 artigo objetiva compreender a legitimidade da aplicação da sanção penal prevista no artigo 268 do Código Penal $^{1}$ para punir infratores de medidas sanitárias preventivas na contenção da doença de Covid-19, na perspectiva da Teoria de Günther Jakobs. Com a rápida disseminação geográfica da doença causada pelo novo coronavírus (Sars-Cov-2), a OMS - Organização Mundial da Saúde declarou em 11 de março de 2020 a pandemia. Em diversos países foram adotadas medidas extremas para a retenção da contaminação mediante o denominado lockdown, consubstanciado em uma série de restrições e proibições, visando um maior distanciamento social entre as pessoas.

No Brasil não foi diferente. Em decorrência do aumento do número de pacientes infectados, de mortes e de países atingidos, o Governo Federal, os Estados e os Municípios anunciaram diversas medidas com o intuito de conter a transmissão do vírus. Nesta direção, foram publicadas a Portaria $356 / 2020^{2}$ e a Portaria Interministerial 05/202033; além, da Lei no $13.979 / 2020$, com um rol de medidas baseadas em evidências científicas a serem adotadas para o enfrentamento da emergência de saúde pública de importância internacional decorrente da pandemia de Covid-19.

A despeito da adoção de medidas para o enfrentamento da doença, houve omissão e afirmações contrárias à ciência as quais partiram, inclusive, daqueles que deveriam dar o exemplo. Essa atitude omissiva e negacionista da ciência contribuiu para a crise humanitária devido ao número alarmante de mortos no Brasil.

Em meados de março de 2020, o Chefe do executivo brasileiro durante discurso em cadeia nacional afirmou ser a Covid-19 uma mera

1. Art. 268 - Infringir determinação do poder público, destinada a impedir introdução ou propagação de doença contagiosa: Pena - detenção, de um mês a um ano, e multa.

2. Dispõe sobre a regulamentação e operacionalização do disposto na Lei $n^{\circ}$ 13.979, de 6 de fevereiro de 2020, que estabelece as medidas para enfrentamento da emergência de saúde pública de importância internacional decorrente do coronavírus (COVID-19), Portaria publicada em 12/03/2020 no Diário Oficial da União.

3. Dispõe sobre a compulsoriedade das medidas de enfrentamento da emergência de saúde pública previstas na Lei no 13.979, de 06 de fevereiro de 2020, Portaria publicada em 17/03/2020 no Diário Oficial da União. gripezinha. Ademais, demitiu um ministro da saúde que defendia o isolamento social como fundamental no combate a pandemia, incentivou tratamento precoce, sem comprovação científica, e criticou duramente medidas que foram adotadas por Estados e municípios no enfrentamento à pandemia de Covid-19.

No final de abril de 2021, o Brasil passou a marca de 400 mil mortes e, neste cenário, a Comissão Parlamentar de Inquérito (CPI) foi instaurada para investigar o Governo brasileiro que recusou, ao menos onze vezes, vacinas contra a doença ${ }^{4}$.

A legislação dispõe sobre as diversas medidas de enfrentamento a serem adotadas pelas autoridades no âmbito de suas competências, dentre elas, o isolamento, a quarentena $\mathrm{e}$ o uso obrigatório de máscaras de proteção individual, com a possibilidade de imputação de responsabilidade penal para os infratores ${ }^{5}$. Neste sentido, cidadãos poderão incorrer na prática de crime de infração de medida sanitária preventiva, caso não cumpram determinações impostas pelo poder público para impedir a propagação da doença. Portanto, é imprescindível registrar que qualquer pessoa que deixar de cumprir as condutas acima elencadas estará agindo em descompasso com a redação do artigo 268 do Código Penal, podendo, por consequente, sofrer as agruras da persecução penal.

Assim, o agente que, mesmo após receber determinação para realizar compulsoriamente exame médico, deixar de realizá-lo (art. 3으, III, "a", da Lei 13.979/20); ou, se isolado por determinação, fugir (artigo 3ㅇ, I, da Lei 13.979/20), incorrerá em crime. Nesta direção,

4. A CPI Covid foi criada para aparar as ações e omissões do governo federal no enfrentamento à pandemia e a falta de oxigênio em Manaus. Castro Augusto. (2021, abril 13). CPI da Covid é criada pelo Senado. Senado Federal. https://www12. senado.leg.br/noticias/materias/2021/04/13/senado-cria-cpida-covid.

De acordo com informações amplamente divulgadas em cadeia nacional, o Brasil teria recusado ao menos 11 vacinas. Guedes, Octavio. (2021, abril 27). CPI da Covid: Governo Bolsonaro recusou 11 vezes ofertas para compras de vacina. G1. https:// g1.globo.com/politica/blog/octavio-guedes/post/2021/04/27/ cpi-da-covid-governo-bolsonaro-recusou-11-vezes-ofertas-paracompras-de-vacina.ghtml

5. 0 artigo $3^{\circ}$ da Portaria interministerial 05/2020 dispõe que: "O descumprimento das medidas previstas no art. $3^{\text {a }}$ da Lei no 13.979, de 2020, acarretará a responsabilização civil, administrativa e penal dos agentes infratores." 
a técnica de tipificação mais compatível com os anseios de antecipação máxima da proteção da saúde da coletividade é o perigo abstrato.

Visando ilustrar o alegado, no Estado de Santa Catarina localizado no sul do Brasil, cuja população estimada no ano de 2020 girou em torno de 7.252.502 habitantes, a Polícia Militar reportou a ocorrência de 4.588 casos, entre os meses de março de 2020 e até o mês em curso de maio de 2021, que envolvem a prática do delito previsto no art. 268 do Código Penal' ${ }^{6}$.

Entretanto, para transformar-se em crime, a conduta descrita na literalidade do tipo legal, em primeiro lugar, deve contrariar o aspecto valorativo da norma. Considere-se, de outro lado, que a sanção penal aplicada só resultará legitimada quando da ofensividade da saúde pública. Tudo isso significa uma profunda mudança de método, tendo em vista que a tipicidade não se esgota na mera subsunção. Mas, se o injusto penal vem dado pelas condutas de perigo abstrato, a sanção penal aplicada já não conta com a legitimidade do princípio da ofensividade e nem com a intervenção mínima.

Disto resulta que, a origem do problema gravita em torno da perspectiva do Direito Penal, frente aos riscos da pandemia, deixar de cumprir sua função de proteção fragmentária e subsidiária; e, por isso, torna-se imperioso indagar: "Em qual modelo teórico, a aplicação da sanção penal para conter a propagação da pandemia de Covid-19 buscará legitimidade?" Supõe-se que, a legitimidade da aplicação sanção penal prevista no artigo 268 do Código Penal encontrará respaldo no postulado teórico construído por Günther Jakobs.

De acordo com a teoria, ao praticar a conduta proibida descrita no tipo legal, o agente rompe expectativas normativas e a pena passa a ter como função demonstrar para a sociedade que, apesar da violação da norma, é possível confiar na sua vigência. Chamada de prevenção geral positiva, Jakobs constrói um novo sistema a partir da função da pena sem qualquer garantia da intervenção penal mínima.

6. Dados obtidos junto a Polícia Militar do Estado de Santa Catarina. PMSC. Business Intelligence (BI), dados coletados e processados em 07/05/2021.Business Intelligence (BI) PMSC.
E, para alcançar o objetivo proposto, este artigo parte do pressuposto de que a aplicação da sanção penal, em razão da forma mais drástica de reação do Estado, deve ser fragmentária e subsidiária. A consequência natural do que acaba de ser exposto, é reservar à sanção penal apenas aquilo que efetivamente perturba o convívio social. Contra o intervencionismo penal, afirma-se que o sistema constitucional vigente, ao configurar um conjunto de garantias, já não permite a instrumentalização política da sanção penal.

Nesta direção, o artigo foi construído em duas etapas. Na primeira etapa, o texto considerou a importância de debater o conceito de crime, sobretudo, na perspectiva do modelo funcional, o qual deixa de proteger a saúde pública $\mathrm{e}$ passa a proteger a estabilidade normativa. Por isso, considerou, também, que o sistema penal concebido nos termos expostos por Jakobs pode representar uma posição puramente formalista do texto da lei.

Inspirado no paradigma da Teoria Sistêmica, o texto ainda avaliou a legitimação da responsabilidade desde o enfoque funcional, porque o castigo simboliza a necessária reação social voltada para o restabelecimento da confiança do sistema, o qual servirá para comprovar, fundamentar e graduar a culpabilidade. Contudo, o artigo também acrescenta, em consequência, a derrubada da política criminal liberal de natureza de "ultima ratio" produzida pela teoria sistêmica.

Em uma segunda etapa, foi adotado o método de ponderação para discutir o conflito entre o direito à liberdade de locomoção e o direito à saúde da coletividade, diante da polêmica em torno da proibição de circulação de pessoas em locais públicos sem o uso obrigatório de máscara de proteção individual. A despeito do alto valor encarnado na liberdade de locomoção, não se pode ignorar a proeminência da saúde da coletividade no contexto de uma pandemia. $E$, ainda que o risco da pandemia constitua a noção-chave da dialética entre ambos os direitos fundamentais em destaque, não se pode pretender transformar o artigo 268 do CP em tipo legal do perigo abstrato.

O crime de perigo abstrato pode não ferir obrigatoriamente $\mathrm{o}$ princípio da intervenção mínima. Todavia, deve ser observado se a saúde 
pública, no atual momento, poderia ser tutelada por outro ramo do direito, como o direito civil ou administrativo. Portanto, para evitar que a interpretação do julgador chegue a resultados expansivos do espectro de incidência do tipo legal, a tutela subsidiária e fragmentária da saúde pública foi determinante para o juízo de ponderação. A partir da ponderação de valores, a interpretação da norma penal ganhou em razoabilidade, equilíbrio e proporcionalidade.

\section{ELEMENTOS TEÓRICOS LEGITIMADORES DA SANÇÃO PENAL}

O crime representa a violação dos sentimentos coletivos da comunidade, os quais consistem naquilo que se entende por bom e correto. Este elemento da Teoria Sistêmica de Jakobs revela a necessária reação social frente ao infrator e devolve ao cidadão honesto sua confiança no sistema. Entretanto, um ordenamento jurídico apoiado na coação penal, somente se justifica quando há incontestável necessidade de proteção aos direitos humanos (Souza, 1999).

Entre os tipos legais que põem em destaque a incolumidade coletiva, está o crime do artigo 268 do CP, cuja conduta proibida objetiva evitar o perigo comum advindo dos fatos que podem atingir a saúde de um número indeterminado de pessoas. Consequentemente, o escopo é punir a violação de uma providência de ordem sanitária preventiva, consubstanciada em medidas adotadas pela administração. A ideia de punir o agente que viola determinação do poder público vincula-se ao crime de perigo abstrato, tendo em vista a presunção absoluta da existência do risco para a coletividade.

Neste aspecto, o perigo abstrato possui estreita relação com a teoria de Jakobs, porque a aplicação da sanção penal se justifica no inevitável restabelecimento da confiança no sistema. Assim, é possível entender a influência direta da teoria na tipificação do crime de perigo abstrato e, consequentemente na aplicação da sanção penal.

Mas, "definir o que seja crime não é tarefa das mais cômodas" (Krebs, 2006). Inclusive, inexiste no atual Código Penal um conceito, como havia preteritamente no Código Criminal do Império ${ }^{7}$

7. Art. $2^{\circ}$ Julgar-se-ha crime, ou delicto:

$1^{\circ}$ Toda a acção, ou omissão voluntaria contraria às Leis penaes.
(1830) e no primeiro Código Penal Republicano ${ }^{8}(1890)$. Hodiernamente, em vigência no Brasil, a composição legislativa que mais se aproxima na tentativa em conceitua-lo é a redação do artigo $1^{0}$ da Lei de Introdução ao Código Penal ${ }^{9}$, limitandose, todavia, a distinguir crime de contravenção (Grego, 2017).

A investigação em torno do conceito é relevante, já que tal ocupação é conferida à denominada teoria do delito, que se preocupa com os requisitos da conduta punível. Assim, vislumbra-se que sua concepção é eminentemente doutrinária, sendo as mais difundidas estabelecidas em formal, material e analítico (Grego, 2017).

Em síntese, enquanto no aspecto formal o crime seria a "violação da norma legal ameaçada com pena" (Santos, 2018), o critério material se distingue ao mostrar o fato punível como "lesão ao bem jurídico protegido no tipo legal" (Santos, 2018). Entretanto, vislumbra-se que tais conceitos não traduzem com precisão o que se entende por crime pois, sobressai-se o aspecto analítico, no qual visa analisar as características ou elementos que compõem a infração penal. Assim, Ernst Beling foi quem enunciou em 1906 o crime como uma ação típica, antijurídica e culpável (Tavares, 2018). O sistema tripartido de fato punível é o dominante na dogmática contemporânea (Santos, 2018).

Parte da doutrina sustenta que a punibilidade também integra o conceito. Todavia, há autores como Juarez Tavares (2018), Pedro Krebs (2006) e Rogério Greco (2017) os quais registram que a punibilidade não faz parte do delito, sendo somente sua consequência, já que ela "se caracteriza por ser um atributo externo ao fenômeno delituoso” (Krebs, 2006, p. 37).

Imprescindível também registrar que parcela da doutrina ${ }^{10}$ entende o crime consubstanciado

8. Art. $2^{\circ}$ A violação da lei penal consiste em acção ou omissão; constitui crime ou contravenção.

9. Considera-se crime a infração penal que a lei comina pena de reclusão ou de detenção, quer isoladamente, quer alternativa ou cumulativamente com a pena de multa; contravenção, a infração penal a que a lei comina, isoladamente, pena de prisão simples ou de multa, ou ambas, alternativa ou cumulativamente.

10. Alguns autores e obras que se posicionam neste sentido são: Damásio Evangelista de Jesus em Direito Penal: parte geral. São Paulo: Saraiva, 1994, p. 94; René Ariel Dotti em Curso de Direito Penal: parte geral. Rio de Janeiro: Forense, 2001, p. 335-339; 
em fato típico e antijurídico, sendo a culpabilidade pressuposto para aplicação da pena. Apenas por fomento ao debate, tem-se que enquanto a literatura alemã está dividida entre o bipartido e o tripartido, no resto da Europa e na América Latina, o modelo tripartido de fato punível encontra-se dominante (Santos, 2018).

Nesse sentido, imperioso registrar os três modelos sucessivos de fato punível da dogmática, quais sejam: o modelo clássico, neoclássico e finalista (Santos, 2018). Todavia, Juarez Tavares também destaca o modelo funcionalista (Tavares, 2018), cujo precursor se sobressai na pessoa do penalista alemão Günther Jakobs.

Para tanto, eles são classificados em sistemas, tendo como objetivo manter sua consistência em função da aplicação de preceitos da lógica formal, principalmente, "da identidade, da não contradição e do terceiro excluído" (Tavares, 2018, 107). Tavares $(2018,108)$ classifica-os, apontando que "o sistema clássico englobaria os enunciados do causalismo; o neoclássico, do neokantismo; o finalista, das categorias lógico-objetivas e o funcionalismo, das modernas elaborações acerca da proteção à estabilidade da norma ou da constitucionalização do direito penal."

Embora já estivesse se configurando no primeiro terço do século XX, o modelo finalista foi se solidificando no pós-guerra com a recuperação e desenvolvimento de uma sociedade que havia sofrido profundas transformações no âmbito político e jurídico (Tavares, 2018). Introduzido no Direito Penal por Hans Welzel, o finalismo revolucionou todas as áreas do conceito de crime tendo por base o seguinte princípio metodológico: "a ação é o conceito central do fato punível e a estrutura final da ação humana fundamenta as proibições e mandados das normas penais" (Santos, 2018, 79).

Segundo a visão finalista, o fato típico é composto por conduta dolosa ou culposa, comissiva ou omissiva; resultado; nexo de causalidade entre a conduta e o resultado e tipicidade (formal ou conglobante) (Grego, 2017). Seu mérito se consolida na avaliação da conduta

Júlio Fabbrini Mirabete em Manual de Direito Penal: parte geral. 16. ed. São Paulo: Atlas, 2000, p. 94 e Celso Delmanto em Código Penal Comentado. Rio de Janeiro: Renovar, 1986, p. 18-19, apud GRECO, Rogério. Curso de Direito Penal: parte geral, volume I. 19a Ed. Niterói/RJ: Impetus, 2017. p. 202. humana sob vieses psicológicos, sociológicos ou antropológicos, deixando de lado os aspectos unicamente jurídicos, como também, o fato de ter encerrado os aspectos externo e interno da conduta punível (Krebs, 2006).

A ilicitude, expressão sinônima à antijuridicidade, consiste na relação de contrariedade entre a conduta do agente e o ordenamento jurídico (Greco, 2017). Assim, há necessidade de que o ofendido tenha capacidade para consentir; que o bem sobre o qual recaia a conduta do agente seja disponível e que o consentimento tenha sido dado anteriormente, ou pelo menos numa relação de simultaneidade à conduta do agente (Greco, 2017).

Por fim, aborda-se a culpabilidade como uma "relação de reprovabilidade ou censurabilidade que une o agente ao fato por ele praticado" (Krebs, 2006, 36). Na verdade, uma espécie de juízo de reprovação pessoal que se faz sobre a conduta ilícita do agente, caracterizando-se pela imputabilidade; potencial consciência sobre a ilicitude do fato e exigibilidade de conduta diversa (Greco, 2017).

Somado ao exposto, e levando-se em consideração a discussão ora levantada, há que posicionar sobre o modelo funcional, desenvolvido na segunda metade do século XX. Neste momento, "a própria sociedade já não busca na produção de bens seu elemento essencial e a vida econômica se basta em seu próprio exercício" (Tavares, 2018, 122).

Aqui, "importante não será mais a lesão de bem jurídico, mas sim a lesão à estabilidade da norma" (Tavares, 2018, 122). Portanto, "o modelo funcional deixa de proteger bens jurídicos e passa a proteger a estabilidade normativa, com vistas a impedir a defraudação ou frustração de expectativas por parte daqueles que não se integram ao sistema" (Tavares, 2018, 122).

Assim, Günther Jakobs, um dos preconizadores deste modelo, define que a ação é "a realização do resultado evitável" (Jakobs, 1974, 309, citado por Tavares, 2018, 123). Nesse sentido, tal vertente vincula "o componente causal à evitabilidade do evento, o que implica subordinar a conceituação da ação ao resultado, ainda que tomado em sentido normativo." (Tavares, 2018, 123). 
A importância da discussão da dogmática penal e a sistematização dos elementos que integram o crime possibilitam ao intérprete da lei um roteiro seguro a seguir, ao analisar se determinado sujeito praticou ou não uma infração penal (Greco, 2017). Por esta razão, este estudo se revela imprescindível para compreender o impacto da pandemia do coronavírus sobre a interpretação da sanção penal aplicada em decorrência da simples infração de medida sanitária preventiva.

Para a teoria sistêmica, o Direito Penal não se limita a proteger bem jurídico, senão que pretende a confiança institucional no sistema. Portanto, a violação da norma do artigo 268 deve ser considerada disfuncional, já não porque lese ou coloque em perigo concreto a saúde pública, senão porque questiona a "confiança institucional" no sistema.

Mas, Delmanto não apenas inclui o crime na categoria do perigo concreto como também afirma que "a incolumidade pública, no particular aspecto da saúde pública" (Delmanto, 2016, 809) é o objeto jurídico protegido ao destacar ser punível a conduta de "infringir determinação do Poder Público, destinada a impedir introdução ou propagação de doença contagiosa" (Delmanto, 2016, 810). Arremata o autor tratar-se de "norma penal "em branco", que se completa com a existência de outra lei, decreto, portaria ou regulamento que tenha caráter de ordem ou proibição e que o complemento "deve visar a impedir a introdução (entrada) ou propagação (difusão) de doença contagiosa (estado mórbido contagioso ao homem)." (Delmanto, 2016, 810).

Assim, é relevante registrar que enquanto o sujeito ativo pode ser qualquer cidadão, o passivo é a sociedade, como também que o elemento subjetivo do tipo penal em apreço é o dolo de perigo, ou seja, a vontade de gerar um risco não tolerado a terceiros, não exigindo, por conseguinte, elemento subjetivo específico e nem se punindo a forma culposa (Nucci, 2015).

Em regra, a doutrina pátria considera a conduta de "perigo comum abstrato (aquele que coloca um número indeterminado de pessoas em perigo, que é presumido pela lei" (Nucci, 2015, 1213). Todavia, Delmanto (2016) realiza uma importante abordagem quando destaca ser o crime do art. 268 do Código Penal de perigo concreto, razão pela qual é transcrita na íntegra sua colocação para melhor compreensão da discussão:

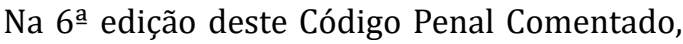
entendíamos que "o crime é considerado de perigo abstrato". Mudamos nossa opinião a partir da 7a edição: em face dos princípios da proporcionalidade e da ofensividade, pensamos que para a caracterização deste crime exige-se prova do perigo concreto, não bastando, pois a simples infração. Com efeito, além de não se poder presumir perigo, bem de ver que nem toda infração à determinação do Poder Público, ainda que destinada a impedir introdução ou propagação de doença contagiosa, colocará em risco o bem jurídico tutelado. Somente o caso concreto dirá. (p. 810)

Nesse sentido, deve a conduta do agente colocar efetivamente em risco o bem jurídico tutelado, o que não poderá dar-se por presunção, ainda que legal (Delmanto, 2016). Justificando o exposto, Delmanto $(2016,810)$ ainda arremata: "imagine-se, por exemplo, a violação de uma determinação do Poder Público que não seja capaz de colocar em risco a saúde pública”.

Portanto, embora o entendimento majoritário da doutrina sobre o crime seja de perigo abstrato, a norma do artigo 268 deve ser aplicada com parcimônia, sob pena de estar-se diante de uma utilização do Direito Penal semelhante ao idealizado por Jakobs, conforme será devidamente abaixo demonstrado.

Ao realizar um resgate histórico sobre a finalidade protetiva de bens jurídicos atribuído ao Direito Penal, Rogério Greco destaca que ela teve início com Birnbaum, em 1834. Antes dele, Feuerbach afirmava que o Direito Penal tinha por fim proteger direitos subjetivos, pois o delito significava uma lesão de um direito subjetivo alheio (Grego, 2017).

Hodiernamente, de acordo com a doutrina majoritária, a finalidade do Direito Penal é a proteção de bens jurídicos, enquanto "a pena, portanto, é simplesmente o instrumento de coerção de que se vale o Direito Penal para a proteção dos bens, valores e interesses mais significativos da sociedade" (Greco, 2017, 2). 
Ratificando o exposto, Nilo Batista $(1996,116)$ registra que "a missão do direito penal é a proteção de bens jurídicos, através da cominação, aplicação e execução da pena", enquanto Luiz Regis Prado $(2011,65)$ destaca que "o pensamento jurídico moderno reconhece que o escopo imediato e primordial do Direito Penal radica na proteção de bens jurídicos - essenciais ao indivíduo e à comunidade".

Todavia, Jakobs contesta essa função ao afirmar que "o Direito Penal não atende a essa finalidade de proteção de bens jurídicos, pois, quando é aplicado, o bem jurídico que teria de ser por ele protegido já foi efetivamente atacado" (Greco, 2017, 3). Assim, “(...) Para Jakobs, o que está em jogo não é a proteção de bens jurídicos, mas, sim, a garantia de vigência da norma, ou seja, o agente que praticou uma infração penal deverá ser punido para que se afirme que a norma penal por ele infringida está em vigor" (Greco, 2017, 3-4).

Portanto, "a concepção desenvolvida por Jakobs não é apenas digna de nota, como constitui aquela que possui a maior originalidade e coerência sistêmica" (Jakobs, 2018, 12), tendo em vista que um dos principais argumentos utilizados pelo autor para sustentar esta posição "radica na (incontestável) ideia de que nem toda perda de um bem é valorada pelo Direito como uma perda juridicamente relevante" (Jakobs, 2018, 12).

Visando ilustrar o acima exposto:

Nem toda perda de um bem [...] é valorada pelo direito como uma perda juridicamente relevante. Assim, a morte de uma pessoa idosa devido à falência múltipla de órgãos não controlável constitui uma perda parentes e amigos ficarão de luto -, mas esta morte não constitui uma perda de um bem compreendido juridicamente. [...] tais perdas constituem perdas de bens, mas não danos que ocorrem dentro do direito, senão fora dele, em uma esfera não abarcada pelo direito (Jakobs, 2018, 45)

Além disso, Jakobs entende ser inadmissível realizar uma análise do direito penal a partir de uma visão normativa que seja separada da realidade social. "Seu funcionalismo, portanto, não aspira meras pretensões normativas, uma vez que ele trata de uma descrição despretensiosa daquilo que é, e não da afirmação do que deve ser" (Jakobs, 2018, 13).

Em suma:

Trata-se, portanto, diretamente da manutenção (e não: melhoramento) da vigência da norma colocada em perigo pela conduta culpável e, por conseguinte, mediatizada pela proteção de bens, em outras palavras, a vigência da norma é, na verdade, o bem jurídico penal; sua manutenção passa diretamente pela pena. 0 bem denominado normalmente de "bem jurídico" - vida, saúde, liberdade, patrimônio etc. - é apenas um motivo para a norma, a representação de um fim. (Jakobs, 2018, 47).

Assim, se entendermos a função da pena como manutenção das estruturas básicas de uma sociedade, o conceito tradicional de bem jurídico também deverá ser reformulado. No homicídio, por exemplo, o bem jurídico não é o dano causado na eliminação da vida de uma pessoa, mas sim um conceito normativo, a vigência da norma.

Para uma sociedade, exemplificando, é básico contar com a expectativa de que se respeitará a vida de seus membros. Assim, quando se comete um homicídio, além de se atentar contra a vida de uma pessoa, também há violação da expectativa de que não se atentará contra a integridade de seus membros. A violação da expectativa é o bem jurídico em sentido penal consistente na proibição de matar (normativo).

É por conta disto que o conflito a ser resolvido por meio da pena não é a agressão do autor contra "fulano ou sicrano", mas sim contra a estrutura normativa da sociedade (Jakobs, 2018). Por isto, diferentemente de autores como Hassemer e Roxin, Jakobs entende não ser correto aceitar que "a sociedade e o Estado devam ser funcionalizados a partir do sujeito." Os sujeitos, caracterizados como pessoas de direito, não nascem como tais, mas sim obtêm seu status no decorrer do processo de socialização", resultando, por conseguinte, que as condições de uma "sociedade que socializa a subjetividade não podem estar subordinadas ao sujeito; pois sem estas condições não se chega a si mesmo" (Jakobs, 2018, 61).

Portanto, "é a vigência da norma, orientadora, que realmente é alvo de ataque, inclusive no caso 
de delitos contra a pessoa - porém, para retomar a questão, não um bem de "fulano e sicrano". A vigência da norma pode ser defendida, isto é, preservada por meio da pena; mas um bem afetado jamais será reparado por meio da pena" (Jakobs, 2018, 65).

Neste diapasão, em síntese, “o dano a ser prevenido por meio do Direito Penal não é o dano aos bens de qualquer pessoa, mas sim um dano social, mais precisamente a iminente erosão da vigência da norma por um fato punível" (Jakobs, 2018, 81).

Apesar da posição de Jakobs, cuja importância decorre do desenvolvimento do funcionalismo sistêmico, "prevalece aquela a respeito da finalidade protetiva de bens que é atribuída ao Direito Penal. Consequentemente, se o Direito Penal tem por fim proteger bens jurídicos, não pode ocorrer a criação típica sem que algum bem esteja sendo por ele tutelado" (Grego, 2017,4).

Portanto, a utilização da teoria visando a punição de crimes associados à transmissão da Covid-19 está na contramão da proteção da saúde, porquanto, a depender da conduta do agente, a aplicação desmedida da sanção penal se assemelhará meramente à manutenção da vigência da lei penal.

E a pena tem função trivial dentro do Direito, porquanto, se trata uma das principais consequências jurídicas do delito (Prado, 2015). Dentre as teorias que justificam sua finalidade três se destacam, quais sejam: as absolutas, as relativas e as teorias unificadoras ou ecléticas, tidas como as teorias mais modernas (Bitencourt, 2018).

As teorias absolutas ou retributivas possuem como característica essencial a pena como um castigo, retribuição ao mal que foi ocasionado por intermédio do delito (Bitencourt, 2018), fundamentando seu existir exclusivamente no delito que foi praticado (Prado, 2004). As teorias relativas preceituam que o fundamento da pena está na prevenção, ou seja, na necessidade de se evitar futuros delitos (Prado, 2015), enquanto a teoria eclética busca reunir no mesmo espaço a retribuição e a prevenção.

No cenário da pandemia, observa-se que a finalidade da pena encontra melhor salvaguarda nas teorias absolutas, mais especificamente na teoria de $\mathrm{Hegel}^{11}$. Isto porque a aplicação da pena insculpida no artigo 268 do Código Penal se justifica unicamente para a reafirmação de uma estrutura jurídica.

Hegel, diferentemente de Kant ${ }^{12}$, entende a pena como algo do campo jurídico (Hegel, 1997). Para o filósofo, o crime constitui uma manifestação avessa ao Direito, uma negação, e a pena vem como uma resposta que deve ser dada no mesmo ímpeto (ou seja, também uma negação), em razão da relação sistêmica entre crime e pena.

A tradição jurídica acabou lendo a pena em Hegel como retribuição, pois não compreendeu o todo do sistema. Hegel admite que no caso concreto a pena seja só compensação e, com isso, faça-se justiça, pois aparece como vingança proporcional. Porém, a função última da pena é afirmar e reafirmar a estrutura do ordenamento do direito como um sistema. E é, portanto, afirmar a própria realização da liberdade. (...) (Salomão; David, 2018, 71-72).

0 criminoso é reconhecido como racional e livre e este ao praticar o ato delituoso nega o Direito diante da sua manifestação de vontade irracional e, por consequente, quer a pena para seu reenquadramento (Hegel, 1997). A racionalidade e a liberdade integram o Direito e o delito constitui uma manifestação de vontade irracional, por isto constitui uma negação (Bitencourt, 2018).

Nas palavras de Hegel "a pena é a negação da negação do Direito”. Portanto, a pena se justifica na necessidade de restaurar a validade da 'vontade geral', que ora foi simbolizada no ordenamento jurídico e foi negado pela vontade do infrator (Bitencourt, 2018), portanto, "funciona como um método próprio do direito de se reafirmar enquanto estrutura e sistema frente ao não direito (crime). Somente assim que se justifica a justiça da pena em Hegel" (Salomão; David, 2018, 71).

Embora existam fortes críticas, e não partam do mesmo ponto, há convergência entre o

11. Assim como Kant, Hegel também está entre os teóricos que emergem as teorias que dão base e fundamento as teorias absolutistas.

12. Kant em sua obra 'Metafisica dos Costumes' entende a pena como uma retribuição ética. 
pensamento de Jakobs e Hegel, já que o crime constitui uma negação da vigência da norma e a pena a negação da negação da norma, logo, a aplicação da pena constitui uma reafirmação do Direito. Todavia, essa não é a melhor solução para o enfrentamento dos problemas advindos de um cenário de pandemia.

Outro aspecto de destaque é força da ultima ratio sobre a sanção penal, a qual não deve ser utilizada antes das outras esferas jurídicas. E mesmo que todas os outros setores falhem, a pena está desvalorizada como instrumento no âmbito teórico, enquanto possibilidade de recuperação de um indivíduo (Carvalho, 2018). Ademais, o sistema carece de melhorias para que a pena possa cumprir suas finalidades precípuas, tanto no seu aspecto repressivo quanto no preventivo.

A aplicação da sanção penal, além de todas as limitações já enfocadas, não resulta legítima quando a atividade criminalizadora do legislador não respeita o núcleo básico do Direito Penal constituído pelo princípio da ofensividade à saúde pública. Se for assim, a pena poderá cumprir seus fins preventivos em decorrência de um fato concreto cuja conduta, por si mesma, encerra uma lesividade potencial. Neste aspecto, inexiste inconstitucionalidade na tipicidade material de infração de determinação do poder público destinada a impedir a introdução ou propagação de doença contagiosa.

\section{DO MÉTODO SUBSUNTIVO AO MÉTODO DE PONDERAÇÃO NA APLICAÇÃO DA SANÇÃO PENAL}

Em uma época com abusiva intervenção estatal cada vez maior, não há dúvida de que uma visão crítica do Direito Penal pode ser obtida mais facilmente com uma concepção fragmentária e subsidiária da ofensividade. Somente essa concepção poderá invocar a legitimidade da ação do Estado desde o ponto de vista da pessoa. Se de um lado é certo que o direito à saúde emerge em virtude das determinações do poder público destinadas a impedir a propagação do vírus, caracterizado pelo uso obrigatório de máscaras em ambientes públicos; de outro, o direito de ir, de vir e de ficar está, também, assegurado pelo artigo 5ำ, inciso XV da Constituição, direito que visa proteger a esfera da autonomia pessoal.

Direito de primeira geração, a liberdade de locomoção possui salvaguarda em diversos documentos internacionais ${ }^{13}$ de Direitos Humanos, assegurado por uma esfera negativa, no que se refere à abstenção do Estado e de terceiros de não interferência na livre circulação pelo território nacional em tempos de paz; e, por sua esfera positiva que imputa ao Estado o dever de proteção dos direitos fundamentais (Sarlet; Marinoni, 2018)

Noutro norte, há que se ressaltar ser a saúde um direito de segunda geração traduzido em direitos de participação, consubstanciandose em um direito social, também previsto na Constituição Federal, em especial nos seus artigos $6^{0}{ }^{14}$ e $196^{15}$

A saúde, interligada com o direito à vida, com o princípio da dignidade humana e a proteção da integridade física do ser humano, é um direito notadamente correlacionado com outros direitos fundamentais, o que o coloca em uma situação de sobreposição com outras esferas e assegura com a sua proteção que outros também sejam protegidos (Sarlet; Marinoni, 2018).

A saúde pública consiste em um direito particular, apoiado no interesse do indivíduo em não ter sua integridade física e biopsicológica prejudicada pela contaminação de substâncias - ar, água, alimentos ou medicamentos imprescindíveis para a vida. Essas substâncias ao se relacionarem com a multiplicidade de homens agrupados mediante uma associação estável, transformam a saúde em direito social. Neste caso, o Direito Penal deve proteger, sem dúvida, bens jurídicos cunhados como essenciais não apenas ao indivíduo, mas também à coletividade. E, toda vez que o ar, a água e os alimentos forem para um número indeterminado de pessoas, sua proteção deve ser objeto de todo e qualquer Direito e não apenas do Direito Penal (Souza, 2006).

13. A título de exemplo podem ser citados o Pacto de Direitos Civis e Políticos, de 1966, a Convenção Americana sobre Direitos Humanos, a Convenção Europeia dos Direitos do Homem (1950) e A Carta de Direitos Fundamentais da União Europeia, de 2000.

14. "São direitos sociais a educação, a saúde, a alimentação, o trabalho, a moradia, o transporte, o lazer, a segurança, a previdência social, a proteção à maternidade e à infância, a assistência aos desamparados, na forma desta Constituição."

15. "A saúde é direito de todos e dever do Estado, garantido mediante políticas sociais e econômicas que visem à redução do risco de doença e de outros agravos e ao acesso universal e igualitário às ações e serviços para sua promoção, proteção e recuperação." 
Na era do triunfo da ponderação, tudo isso significa uma profunda mudança de método que já não se esgota na mera subsunção. A consequência inevitável é a proeminência do juiz sempre que o legislador descuida da razoabilidade e do equilíbrio na criação de tipos legais. E, não resta dúvida que a ponderação pode ser realizada pelo juiz. Considere-se, de outro lado, que é da essência da lei contemplar casos genéricos, não casos concretos, podendo estabelecer regras favoráveis à saúde pública ou à liberdade de locomoção em eventual colisão. Em outras palavras, a colisão entre eles são resolvidas pelo juiz no caso concreto e não pela lei penal.

Os direitos fundamentais não podem ser tidos como absolutos, inclusive na hipótese de quando se defrontam com outros de igual preponderância. Assim, vislumbra-se que o novo coronavírus acaba impondo uma esgrima entre ambos direitos fundamentais, devendo-se adotar a proporcionalidade como uma solução que busque equacionar o problema. Além do significado político-criminal, a proporcionalidade tem função dogmática destinada a orientar o intérprete e o Poder Judiciário a fim de atender não só ao conteúdo do injusto penal, senão que contribuir para a formação do complexo conceito da culpabilidade.

A proporcionalidade surge como um mecanismo de função necessária e com a tarefa de mediar e mensurar a força do uso do princípio da igualdade quando do conflito entre direitos fundamentais (Agra, 2018). 0 princípio não possui como objetivo limitar as liberdades constitucionais, mas sim assegurar sua proteção e implementar, restringindo a liberdade individual somente em situações de violação ao bem comum. Além disso, a limitação da liberdade de locomoção somente deve ocorrer quando estritamente necessária ao interesse geral da sociedade e em hipóteses expressamente consignadas na Constituição Federal (Agra, 2018).

No conflito entre o direito de locomoção e o direito à saúde da coletividade deve prevalecer este último, sobretudo, quando a ponderação considera o momento atual da pandemia. Neste caso, revela-se a razão do interesse público e da necessidade de resguardar o bem comum. Todavia, a prevalência de um direito fundamental sobre o outro não implica automaticamente na possibilidade do uso desmedido da esfera penal. 0
Direito Penal é guiado por princípios que também são provenientes da Constituição Federal, devendo se incumbir e tutelar os bens de maior importância e imprescindíveis para à coabitação em sociedade (Greco, 2017), condicionando-se sua aplicação à falha dos outros setores, levandose em consideração o seu aspecto subsidiário (Sanches, 2016).

Emanadas do poder público, é certo que a inobservância das providências, destinadas a impedir a propagação do vírus, constitui medida prejudicial para o enfrentamento da pandemia. Do mesmo modo, sabe-se da existência de inúmeros outros instrumentos jurídicos e administrativos muito mais eficientes e, que devem anteceder ao Direito Penal para o exercício de eventual coercibilidade e sanção para aqueles que ofendem a saúde pública.

A contenção da propagação do novo vírus mediante a obrigatoriedade do uso de máscaras em ambientes e vias públicas é crime de perigo concreto quando for ofensivo ao bem jurídicopenal. $\mathrm{O}$ homem tem o direito à vida e a saúde; mas, quando há um perigo comum indeterminado e geral para as pessoas que vivem em sociedade que excede o perigo individual, então ofendese a chamada saúde pública. Trata-se de crime que não ofende tão-somente a integridade física e biopsicológica da pessoa ou das muitas individualmente consideradas, mas de qualquer delas ou de todas elas conjuntamente (Souza, 2006).

Pois bem, o cidadão que se recusar a utilizar a máscara em ambientes públicos, e em contrariedade com a determinação do poder público poderá também sofrer a sanção prevista no artigo 268 do Código Penal. Entretanto, o ordenamento jurídico tem condições de oferecer à saúde pública uma proteção diferenciada na esfera civil e administrativa, por exemplo. Em outras palavras, a tutela só deve ser reservada ao Direito Penal quando outros ramos do direito não solucionam satisfatoriamente o conflito.

A persecução penal encontra seu limite no fato do conflito poder ser solucionado por outro meio menos gravoso, razão pela qual o direito penal não deve interferir quando o direito administrativo for capaz de oferecer a necessária proteção. A intervenção da lei penal ocorrerá, de acordo com Luiz Regis Prado $(2015,117)$, "quando for 
absolutamente necessária para a sobrevivência da comunidade - como ultima ratio legis -, ficando reduzida a um mínimo imprescindível. $\mathrm{E}$, de preferência, só deverá fazê-lo na medida em que for capaz de ter eficácia...

Em contrariedade com as normas vigentes, a recusa em não utilizar máscaras em ambientes públicos merece aplicação de multas e outras medidas de natureza administrativa muito mais eficazes; razão pela qual se justifica a incidência do Princípio da Intervenção Mínima pela via da fragmentariedade e da subsidiariedade.

\section{CONCLUSÃo}

Este artigo se propôs a compreender a legitimidade da aplicação da sanção penal prevista no artigo 268 do Código Penal, como instrumento na contenção da transmissão do vírus, a partir da função do Direito Penal proposta pela Teoria de Günther Jakobs. Neste sentido, afirmou-se que a punição pela prática da conduta proibida se legitima apenas na perspectiva da sua teoria, eis que a sanção funciona na manutenção da vigência da lei penal e não na proteção da saúde da coletividade.

Mas, também, discutiu-se a legitimidade da sanção penal na perspectiva dos princípios da ofensividade, da proporcionalidade e da intervenção mínima, sobretudo para aplicar o método de ponderação e, assim, ofertar uma solução racional diante do conflito entre o direito de locomoção e o direito à saúde pública.

Os princípios da fragmentariedade e da subsidiariedade são garantias concretas de afastamento da aplicação da sanção penal em determinadas situações, isto porque com a atuação de outras esferas jurídicas na proteção do mesmo bem jurídico, emerge a possibilidade de incidência da intervenção mínima. Mas, em que pese a incidência da intervenção mínima, não se pode ignorar que os limites entre a matéria administrativa e a matéria penal ainda não se encontram bem definidos.

Por isso, parece oportuno reconhecer e sublinhar que a aplicação de sanção penal para quem não se utiliza de máscara dentro das circunstâncias estabelecidas em protocolos municipais, estaduais ou federais afasta a lei penal da generalidade e, a transforma em instrumento voltado para a solução de situações particulares ou emergenciais, como é o caso da pandemia. A consequência natural do que acaba de ser exposto é a ampliação excessiva da possibilidade de qualquer pessoa tornar-se um criminoso.

Ademais, a teoria sistêmica pretende a confiança institucional no sistema e o convencimento da sociedade em seu bom funcionamento. Essa máxima inspira também uma outra concepção de culpabilidade, pois a exigência funcionalista de restabelecer a confiança na ordem jurídica mediante a aplicação de uma pena prescinde da capacidade real do agente de ter atuado na direção estabelecida pela norma. Em outras palavras, não aparece mais na base do juízo de culpabilidade a capacidade concreta do agente de ter atuado diversamente como o fez. Este lugar é ocupado pelo restabelecimento da confiança no sistema, pois é assim que a pena é legitimada e, é este o critério decisivo para constatar e graduar a culpabilidade.

Entretanto, diferentemente do que é afirmado pela Teoria de Jakobs, a utilização da sanção penal para resolver a emergência da pandemia contribui para a falta de confiança no sistema. Logo, em muitos casos, o correto será a mudança da tutela, de penal passaria a ser administrativa ou civil. Todavia, a dogmática penal não enfrenta seriamente esse problema, porque aprendeu a se compaginar com a hipertrofia penal.

No conflito entre liberdade individual e saúde pública deve prevalecer o interesse público, o bom senso e a empatia individual de cada um a fim de contribuir para o enfrentamento da Pandemia de Covid-19, já que em um momento tão delicado apenas se mostra razoável a aplicação da sanção penal sob a ótica da sua intervenção mínima. Informações intensivas e sanções administrativas, como multas, são muito mais racionais porque têm aplicação rápida e efetiva.

Em tempos de pandemia, um bom guia para mudança de postura consiste na reafirmação dos princípios limitadores do ius puniendi estatal. Portanto, a redução drástica da aplicação da sanção penal deve ocupar o centro da aspiração político-criminal racional do artigo 268 do Código Penal. Enfim, a aplicação da sanção penal no atual contexto não possui racionalidade e, por isso, está perdida, como diria Louk Hulsman, criminólogo holandês, conhecido por desenvolver a teoria do abolicionismo penal. 


\section{BIBLIOGRAPHY}

- Agra, Walber de Moura. (2018). Curso de Direito Constitucional. (9. ed.). Editora Fórum.

- Batista, Nilo. (1996). Introdução Crítica ao direito penal brasileiro. p. 48. Revan.

- Bitencourt, Cezar Roberto. (2018). Tratado de Direito Penal: parte geral 1. (24. ed.). Saraiva.

- Carvalho, Amilton Bueno de. (2018). Direito Penal a Marteladas. (2. Ed.) Lumen Juris.

- Delmanto, Celso, et al. (2016). Código Penal Comentado. (9. ed.). Saraiva.

- Greco, Rogério. (2017). Curso de Direito Penal: parte geral. (19. ed.) Niterói/RJ: Impetus.

- Hegel, George Wilhelm Friedrich. (1997). Princípios da filosofia do direito. Martins Fontes, 1997.

- Jakobs, Günther. (1974) "Vermeidbares Verhalten und Strafrechtssystem", in Festschrift für Welzel, Berlin: De Gruyter. In: Tavares, Juarez. (2018). Fundamentos de Teoria do Delito. Tirant lo Blanch.

- Jakobs, Gunter (org.). (2018). Proteção de bens jurídicos?: sobre a legitimação do direito penal. Livraria do Advogado.

- Krebs, Pedro. (2006). Teoria Jurídica do Delito: noções introdutórias: tipicidade objetiva e subjetiva. (2. ed.) Manole.

- Nucci, Guilherme de Souza. (2015). Código Penal Comentado. (15. ed.). Forense.

- Prado, Luiz Regis. (2011). Bem jurídicopenal e Constituição. (5. ed.) Revista dos Tribunais.

- Prado, Luiz Regis. Carvalho, Érika Mendes de. Carvalho, Gisele Mendes de. (2015). Curso de Direito Penal brasileiro. (14. ed.) Revista dos Tribunais.

- Prado, Luiz Regis. (2004) Teoria dos fins da pena: breves reflexões. São Paulo: RT, Revista Ciências Penais, v.0. http:// regisprado.com.br/Artigos/Luiz\%20 Regis \% 20 Prado/Teoria $\% 20$ dos $\% 20$ fins\%20da\%20pena.pdf.

- Salomão Neto, Antônio. David, Décio Franco. (2018). Reflexões sobre a pena em Hegel: (in)compreensão e dificuldade de superação. Revista Justiça e Sistema Criminal. v. 10 , n. 18, p. 59-80. https:// revistajusticaesistemacriminal.fae.edu/ direito/article/view/137/110

- Sanches, Rogério Cunha. (2016). Manual de Direito Penal. (4. ed.) Salvador: JusPODIVM.

- Santos, Juarez Cirino dos. (2018). Direito Penal: parte geral. (8. ed.) Tirant lo Blanch.

- Sarlet, Ingo Wolfgang. Marinoni, Guilherme Luiz. Mitidiero, Daniel. (2018). Curso de Direito Constitucional. (7. ed.) Saraiva Educação.

- Souza, Cláudio Macedo de. (1999). A construção política da pena. Revista de Direito Comparado, Belo Horizonte, v. 3, n. 3, p. 375-381.

- Souza, Cláudio Macedo de. (2006). Direito Penal no Mercosul: uma metodologia de harmonização. Belo Horizonte: Mandamentos.

- Tavares, Juarez. (2018). Fundamentos de Teoria do Delito. Tirant lo Blanch. 